\title{
EDITORIAL
}

\section{Op het podium met Nederlands onderzoek}

\author{
Peter F. A. Mulders ${ }^{1}$
}

Published online: 29 October 2019

(C) The Author(s) 2019

Het podium op. Dat wordt veelvuldig gedaan met Nederlands onderzoek door arts-onderzoekers, arts-assistenten en urologen. Vaak gaat dit via ingediende abstracts, waarop dan later een publicatie volgt, die aangeboden wordt aan een internationaal tijdschrift. Het is echter ook goed om zo'n artikel aan te bieden aan het Nederlands Tijdschrift voor Urologie. Dien ook zeker abstracts in voor de wetenschappelijke vergaderingen van de NVU, want uit wat daar wordt gepresenteerd, maakt de redactie een nieuwe selectie, om de auteurs van die abstracts actief uit te nodigen een artikel in te dienen.

In dit nummer is een rapportage gepubliceerd van de FUTURE trial; een multicenter RCT naar MRI-geleide prostaatbiopten. In die trial zijn drie technieken gebruikt voor het nemen van targetbiopten en het resultaat ervan is vervolgens vergeleken met het resultaat van systematische biopten. Het adequaat nemen van prostaatbiopten en de methode standaardiseren is cruciaal voor het advies dat we daarna aan de patiënt geven voor zijn prostaatkankerbehandeling.

Ik hoop bij deze weer velen van jullie uitgedaagd te hebben om, behalve abstracts, ook rechtstreeks oorspronkelijke artikelen (eventueel vertaald) in te sturen, zodat we een goede mix blijven houden in het wetenschappelijk gedeelte van het tijdschrift.

Veel leesplezier, ook bij de rariteiten die in de overigens zeer interessante casuïstiek beschreven staan.

Open Access This article is distributed under the terms of the Creative Commons Attribution 4.0 International License (http:// creativecommons.org/licenses/by/4.0/), which permits unrestricted use, distribution, and reproduction in any medium, provided you give appropriate credit to the original author(s) and the source, provide a link to the Creative Commons license, and indicate if changes were made.

Prof. dr. Peter F.A. Mulders uroloog, wetenschappelijk sectieredacteur
Prof. dr. Peter F. A. Mulders

peter.mulders@radboudumc.nl

1 Afdeling Urologie, Radboud Universitair Medisch Centrum Nijmegen, Nijmegen, Nederland 